Article

\title{
Polyphenol-Rich Strawberry Extract Protects Human Dermal Fibroblasts against Hydrogen Peroxide Oxidative Damage and Improves Mitochondrial Functionality
}

\author{
Francesca Giampieri ${ }^{1}$, José M. Alvarez-Suarez ${ }^{1,2,6, *}$, Luca Mazzoni ${ }^{2}$, \\ Tamara Y. Forbes-Hernandez ${ }^{2,6}$, Massimiliano Gasparrini ${ }^{2}$, Ana M. Gonzàlez-Paramàs ${ }^{3}$, \\ Celestino Santos-Buelga ${ }^{3}$, José L. Quiles ${ }^{4}$, Stefano Bompadre ${ }^{5}$, Bruno Mezzetti ${ }^{1}$ \\ and Maurizio Battino $2,7, *$
}

1 Dipartimento di Scienze Agrarie, Alimentari e Ambientali, Università Politecnica delle Marche, Via Ranieri 65, Ancona 60131, Italy; E-Mails: f.giampieri@univpm.it (F.G.); b.mezzetti@univpm.it (B.M.) Dipartimento di Scienze Cliniche Specialistiche ed Odontostomatologiche (DISCO)-Sez. Biochimica, Facoltà di Medicina, Università Politecnica delle Marche, Ancona 60131, Italy;

E-Mails: 1.mazzoni@univpm.it (L.M.); tamara.forbe@gmail.com (T.Y.F.-H.); m.gasparrini@univpm.it (M.G.)

3 Grupo de Investigación en Polifenoles (GIP-USAL), Faculty of Pharmacy, Salamanca University, Campus Miguel de Unamuno, Salamanca E37007, Spain; E-Mails: paramas@usal.es (A.M.G.-P.); csb@usal.es (C.S.-B.)

4 Department of Physiology, Institute of Nutrition and Food Technology “José Mataix”, Biomedical Research Centre, University of Granada, Granada 18100, Spain; E-Mail: jlquiles@ugr.es

5 Dipartimento di Scienze Biomediche e Sanità Pubblica, Facoltà di Medicina, Università Politecnica delle Marche Via Ranieri 65, Ancona 60131, Italy; E-Mail: s.bompadre@univpm.it

6 Area de Nutrición y Salud, Universidad Internacional Iberoamericana (UNINI), Campeche, C.P.24040, Mexico

7 Director Centre for Nutrition \& Health, Universidad Europea del Atlantico (UEA), Santander 39011, Spain

* Authors to whom correspondence should be addressed; E-Mails: j.m.alvarez@univpm.it (J.M.A.-S.); m.a.battino@univpm.it (M.B.); Tel.: +39-071-220-4136 (J.M.A.-S.); +39-071-220-4646 (M.B.); Fax: +39-071-220-4123 (J.M.A.-S. \& M.B.).

Received: 30 April 2014; in revised form: 5 June 2014 / Accepted: 6 June 2014 / Published: 11 June 2014

Abstract: Strawberry bioactive compounds are widely known to be powerful antioxidants. In this study, the antioxidant and anti-aging activities of a polyphenol-rich strawberry 
extract were evaluated using human dermal fibroblasts exposed to $\mathrm{H}_{2} \mathrm{O}_{2}$. Firstly, the phenol and flavonoid contents of strawberry extract were studied, as well as the antioxidant capacity. HPLC-DAD analysis was performed to determine the vitamin $\mathrm{C}$ and $\beta$-carotene concentration, while HPLC-DAD/ESI-MS analysis was used for anthocyanin identification. Strawberry extract presented a high antioxidant capacity, and a relevant concentration of vitamins and phenolics. Pelargonidin- and cyanidin-glycosides were the most representative anthocyanin components of the fruits. Fibroblasts incubated with strawberry extract and stressed with $\mathrm{H}_{2} \mathrm{O}_{2}$ showed an increase in cell viability, a smaller intracellular amount of ROS, and a reduction of membrane lipid peroxidation and DNA damage. Strawberry extract was also able to improve mitochondrial functionality, increasing the basal respiration of mitochondria and to promote a regenerative capacity of cells after exposure to pro-oxidant stimuli. These findings confirm that strawberries possess antioxidant properties and provide new insights into the beneficial role of strawberry bioactive compounds on protecting skin from oxidative stress and aging.

Keywords: strawberry; anthocyanin; ROS; lipid peroxidation; DNA damage; fibroblasts

\section{Introduction}

There is evidence that oxidative stress, exerting downstream effects such as lipid peroxidation, DNA damage and mitochondrial impairment, may have a causative role in skin disease and aging [1,2]. The skin is the largest organ of the body that creates a self-repairing barrier, protecting the body from the most common potentially harmful physical, environmental, and biological insults. Indeed, there are many factors to which skin is exposed like smoke, microorganisms, or UV radiation, that can induce biological responses, leading to skin damage through the generation of reactive oxygen species (ROS). Human dermal fibroblasts $(\mathrm{HuDe})$ are the main experimental model in vitro for studying cellular aging [3,4]; at the same time, some agents such as $\mathrm{H}_{2} \mathrm{O}_{2}$, UV-radiation and lipopolysaccharide are usually used to induce HuDe oxidative damage and premature senescence [5,6]. In recent years several studies have shown that oxidative stress and senescence in human fibroblasts can be counteracted and delayed by certain protective antioxidant compounds [1,4,7]: dietary vitamins and polyphenols are indeed able to ameliorate oxidative skin damage and prevent aging, even if the role of diet in protecting the skin is highly controversial due to the limited amount of scientific data available [8]. For these reasons, in the last few years topical treatment of these compounds has been proposed as a strategic tool in order to provide additional protection from oxidative damage and delay skin aging [8,9].

The strawberry (Fragaria x ananassa) is one of the richest natural sources of bioactive compounds, like vitamin $\mathrm{C}, \beta$-carotene and polyphenolics (phenols, flavonoids, phenolic acids, lignans, and tannins) which express remarkable antioxidant capacities both in vitro and in vivo [10,11]. Over the last decade, our research has addressed not only the characterization of the nutritional quality of several strawberry genotypes but also the in vitro and in vivo assessment of the effects of strawberry treatment/consumption on antioxidant status [1,12-15]. The aim of the present study is to evaluate the in vitro effects of a polyphenol-rich strawberry extract in cytoprotection against oxidative stress using 
$\mathrm{H}_{2} \mathrm{O}_{2}$ as stressors in HuDe cells, since it represents a valid model for studying oxidative stress and senescence on cells. We evaluated the protective effects of strawberry extract on cell viability, ROS concentration, lipid peroxidation and DNA damage. Finally, because mitochondria are the main source of reactive species, which are by-products of cell energy production, within most cells and are the main organelles involved in the aging phenotype, we also assessed the protective effects of strawberry extract on mitochondrial status and functionality.

\section{Results and Discussion}

\subsection{Nutrients, Phenolics and Antioxidant Capacity of Strawberry Extracts}

According to our previous results [1], the Sveva cultivar is a remarkable source of phenols and flavonoids (Table 1); five anthocyanin pigments were detected through HPLC-DAD/ESI-MS analysis, with Pg- and Cy-glycosides being the most representative anthocyanin strawberry components (Table 1). Pg-3-glucoside is the most abundant, with $61.12 \mathrm{mg} / 100 \mathrm{~g} \mathrm{FW}$, followed by Cy-3-glucosides, with a concentration of about $1.63 \mathrm{mg} / 100 \mathrm{~g} \mathrm{FW}$.

Table 1. Nutrient composition, phytochemical content and antioxidant capacity of strawberry extract.

\begin{tabular}{cc}
\hline Parameter & Quantification \\
\hline Vitamin C $(\mathrm{mg} / \mathrm{g})$ & $0.47 \pm 0.04$ \\
$\beta$-Carotene $(\mu \mathrm{g} / \mathrm{100} \mathrm{g})$ & $25 \pm 0.02$ \\
Total phenolic $(\mathrm{mg} / \mathrm{g})$ & $2.19 \pm 0.09$ \\
Total flavonoid $(\mathrm{mg} / \mathrm{g})$ & $0.70 \pm 0.01$ \\
Anthocyanins $(\mathrm{mg} / 100 \mathrm{~g})$ & \\
Cy-3-glucoside & $1.63 \pm 0.04$ \\
Pg 3-glucoside & $61.12 \pm 0.13$ \\
Pg 3-rutinoside & $0.19 \pm 0.01$ \\
Pg 3-malonylglucoside & $0.28 \pm 0.02$ \\
Pg 3-acetylglucoside & $0.72 \pm 0.03$ \\
TAC ( $\mu$ mol TE/g) & \\
FRAP & $14.94 \pm 0.39$ \\
TEAC & $22.59 \pm 0.9$ \\
\hline
\end{tabular}

Two important antioxidant compounds present in the strawberry are vitamin $\mathrm{C}$ and $\beta$-carotene. As previously reported by different authors $[11,16]$, they are versatile antioxidants, preventing both singlet oxygen and free radical mediated damage. Based on these findings, we analysed the vitamin $\mathrm{C}$ and $\beta$-carotene content of the extract by HPLC-DAD (Table 1) and found a good content of these compounds (about $47.9 \mathrm{mg} / 100 \mathrm{~g} \mathrm{FW}$ and $25 \mu \mathrm{g} / 100 \mathrm{~g} \mathrm{FW}$, respectively), that could contribute to the high antioxidant capacity and free radical scavenging capacity of this cultivar.

The TAC of fruit extract was quantified by FRAP and TEAC assays (Table 1). Sveva extract showed a high TAC value, according to these methods, being $14.94 \mu \mathrm{mol} \mathrm{TE} / \mathrm{g}$ and $22.59 \mu \mathrm{mol} \mathrm{TE} / \mathrm{g}$ of FW for FRAP and TEAC, respectively. We found that TAC values of the Sveva cultivar were 
similar to those previously reported in other strawberry varieties, and confirmed that this cultivar possesses a high TAC [1].

\subsection{Cytotoxicity Evaluation}

Firstly, the possible toxic effect of the strawberry extract in relation to its increasing concentration and exposure time was studied (Figure 1).

Figure 1. Viability of Human Dermal fibroblast (HuDe) determined by MTT assay after incubation with different concentrations of strawberry extract and at different times. Data are expressed as mean \pm SEM for eight replicas $(n=8)$ of three independent experiments.

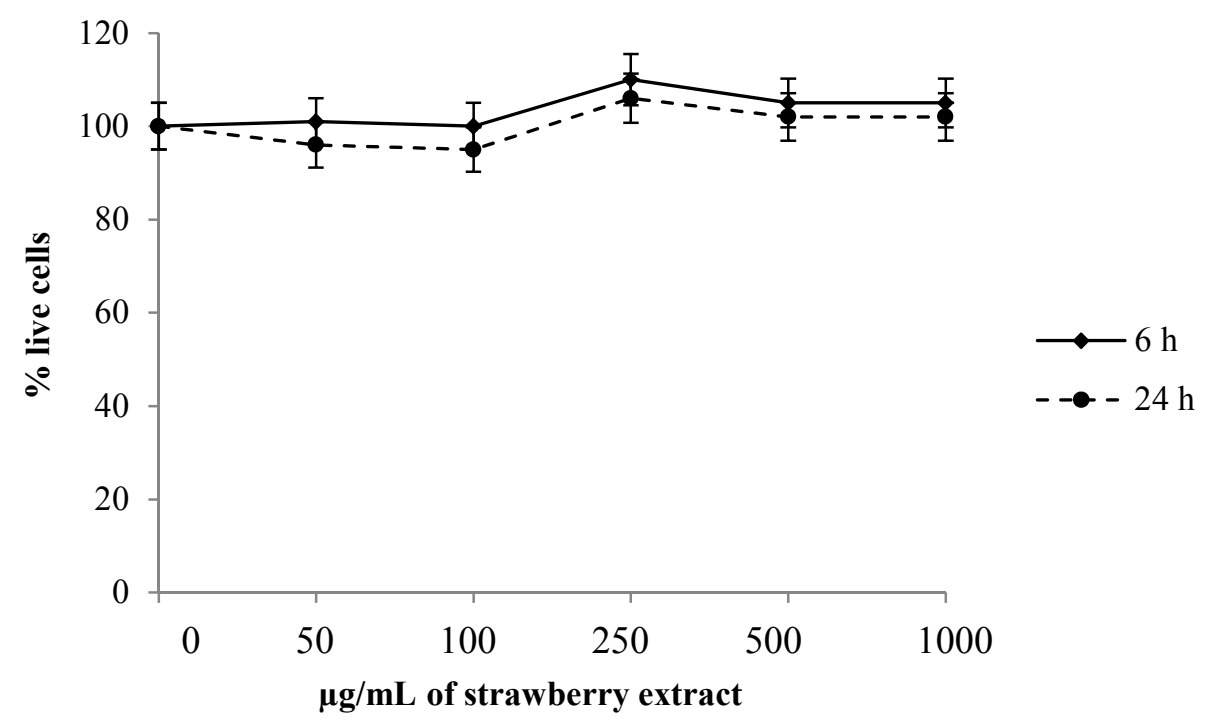

Figure 2. Viability of Human Dermal fibroblast (HuDe) determined by MTT assay after incubation with $\mathrm{H}_{2} \mathrm{O}_{2}$. Control and strawberry pre-treated cells $(0.5 \mathrm{mg} / \mathrm{mL})$ were stressed with various concentrations of $\mathrm{H}_{2} \mathrm{O}_{2}(0-50 \mathrm{mM})$. Cells with extract differ significantly from controls for concentrations of $\mathrm{H}_{2} \mathrm{O}_{2}$ between 0.5 and $5 \mathrm{mM}$. Data are expressed as mean \pm SEM for eight replicas $(n=8)$ of three independent experiments. ${ }^{*} p<0.05$ significantly different from control.

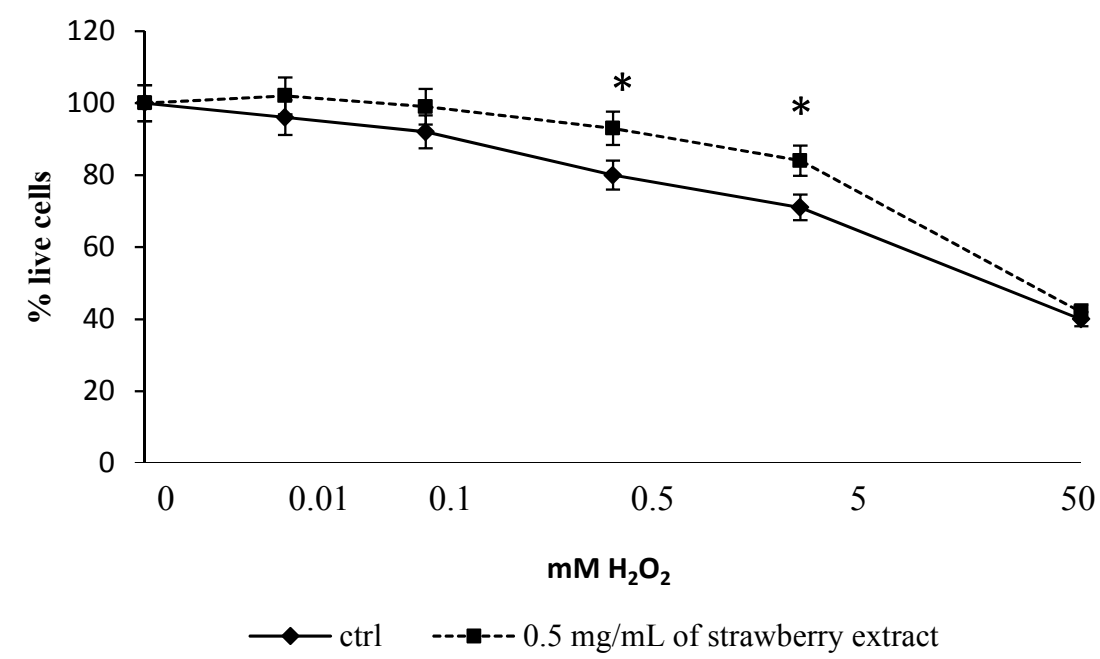


Cell vitality did not vary depending on the strawberry extract concentration or the exposure time, thus no cytotoxic effect was found at the chosen experimental conditions. Therefore, the extract concentration that gave the best results in terms of cell viability and reproducibility $(0.5 \mathrm{mg} / \mathrm{mL})$ was selected for all the tests.

After incubation with $\mathrm{H}_{2} \mathrm{O}_{2}$ for $1 \mathrm{~h}$, only strawberry pre-treated cells did not show a significant decrease in their viability (Figure 2), especially at $\mathrm{H}_{2} \mathrm{O}_{2}$ concentration of 0.5 and $5 \mathrm{mM}$, where cell viability remained higher than $80 \%(p<0.05)$ compared to control cells.

Figure 3. Levels of ROS following $\mathrm{H}_{2} \mathrm{O}_{2}$-induced stress. Control and strawberry extract pre-treated cells were incubated with $\mathrm{H}_{2}$ DCFDA and then stressed with different concentrations of $\mathrm{H}_{2} \mathrm{O}_{2}(0-10 \mathrm{mM})$. The kinetics of fluorescence was studied for two hours. Variation of fluorescent signal is significant already after $15 \mathrm{~min}$ of stress for $\mathrm{H}_{2} \mathrm{O}_{2} \geq 5 \mathrm{mM}$ and after $30 \mathrm{~min}$ for concentrations of $2.5 \mathrm{mM}$. Results are reported as mean DCF fluorescence activity (arbitrary units) obtained from at least three separate experiments (error bars represent SEM). ${ }^{*} p<0.05$ significantly different from control, ** $p<0.01$ highly significant compared to control.
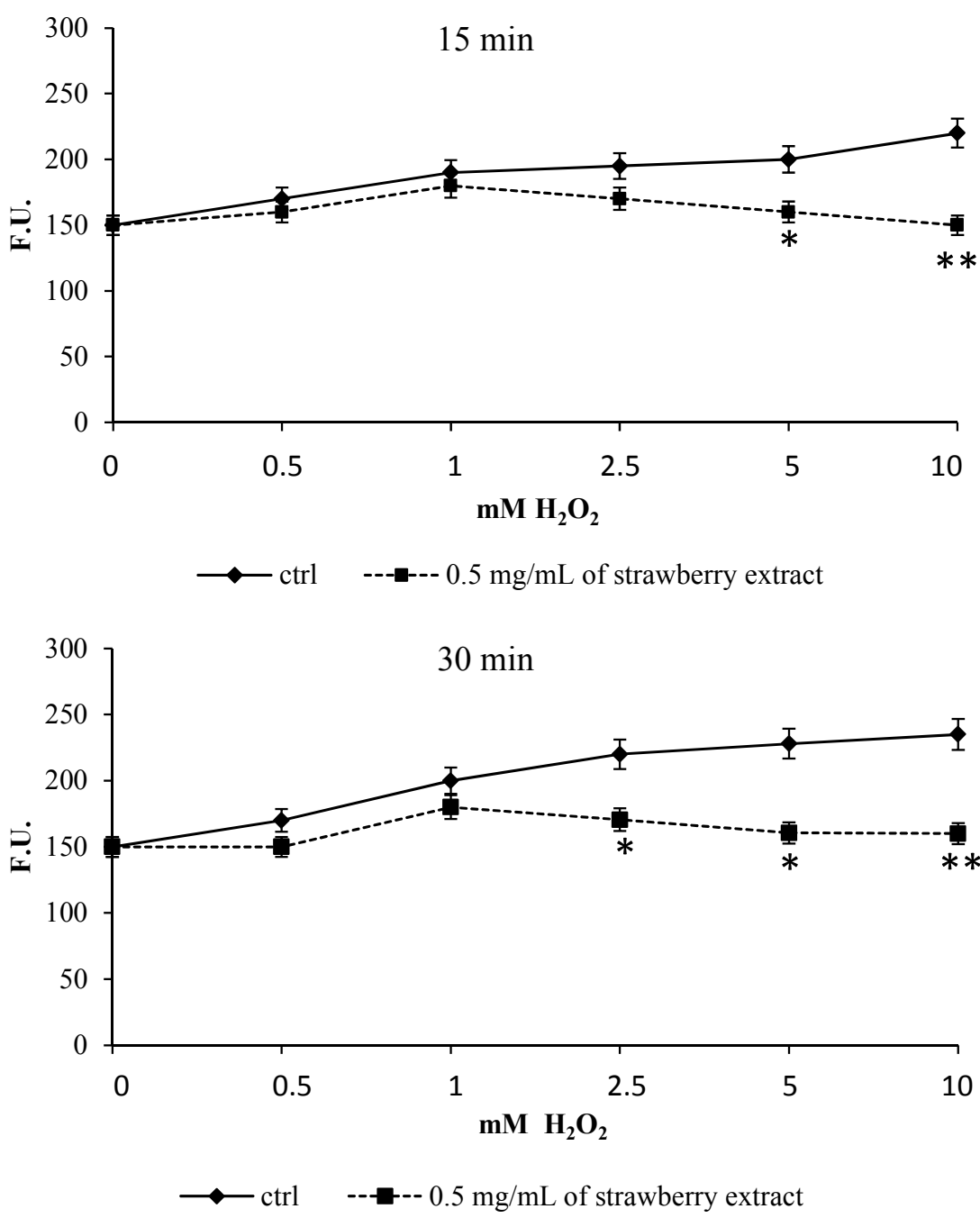


\subsection{Intracellular ROS Production and Lipid Peroxidation}

Incubation with strawberry extract was able to decrease intracellular ROS production induced by $\mathrm{H}_{2} \mathrm{O}_{2}$-mediated oxidative damage. Results shown in Figure 3 are expressed as changes in cell fluorescence versus oxidant concentrations for different incubation times. After 15 min of incubation with $\mathrm{H}_{2} \mathrm{O}_{2}$ a significant difference of fluorescence was found between control cells and cells incubated with the strawberry extract, especially for $\mathrm{H}_{2} \mathrm{O}_{2}$ concentration $\geq 5 \mathrm{mM}(p<0.05)$ and $\mathrm{H}_{2} \mathrm{O}_{2} \geq 10 \mathrm{mM}$ $(p<0.01)$. After $30 \mathrm{~min}$ of incubation, a significant difference $(p<0.05)$ was also found in cells stressed with $\mathrm{H}_{2} \mathrm{O}_{2} \geq 2.5 \mathrm{mM}(p<0.05)$ and these differences remained along all the experimental interval times tested (up to $120 \mathrm{~min}$ ).

Part of the protective effects of the strawberry extract may be reasonably attributed to its anthocyanin fraction. In fact, Cy-3-rhamnoglucoside has been found to be very efficient in scavenging free radicals [17] and at the same time anthocyanidins seem to be able to protect human foetal lung fibroblasts from toxicity induced by linoleic acid hydroperoxide: this could be due to the fact that anthocyanins and their glycosidic forms act as antioxidants in lipid environments in vitro [18].

Cells pre-incubated with Sveva also showed a significant decrease $(p<0.05)$ in lipid peroxidation (Figure 4), especially for $\mathrm{H}_{2} \mathrm{O}_{2} 5 \mu \mathrm{M}$ and a highly significant one $\left(p<0.01\right.$ ) for $\mathrm{H}_{2} \mathrm{O}_{2} \geq 50 \mu \mathrm{M}$ compared to controls. Again, strawberry extract provided protection at cell membrane levels thanks to its anthocyanin that localizes on the polar surfaces of phospholipid bilayers in a region suitable for scavenging aqueous oxygen radicals and lipophilic radicals incorporated into the membranes [17,18]. In accordance with these results and with our findings, we can suppose that the prevention of lipid peroxidation through the scavenging of lipid hydroperoxides could be one of the routes by which anthocyanins can protect cells from oxidative damage.

Figure 4. Evaluation of lipid peroxidation after $\mathrm{H}_{2} \mathrm{O}_{2}$ stress. Control and pre-treated cells with extract were incubated with BODIPY for $30 \mathrm{~min}$ and stressed with different concentrations of $\mathrm{H}_{2} \mathrm{O}_{2}(0-500 \mu \mathrm{M})$. The relationship between red and green fluorescence over time decreases significantly for concentrations of $5 \mu \mathrm{M}$ hydrogen peroxide and highly significantly for concentrations $\geq 50 \mu \mathrm{M}$ compared to controls. Data are expressed as mean \pm SEM for eight replicas $(n=8)$ of three independent experiments. ${ }^{*} p<0.05$ significantly different from control, $* * p<0.01$ highly significant.

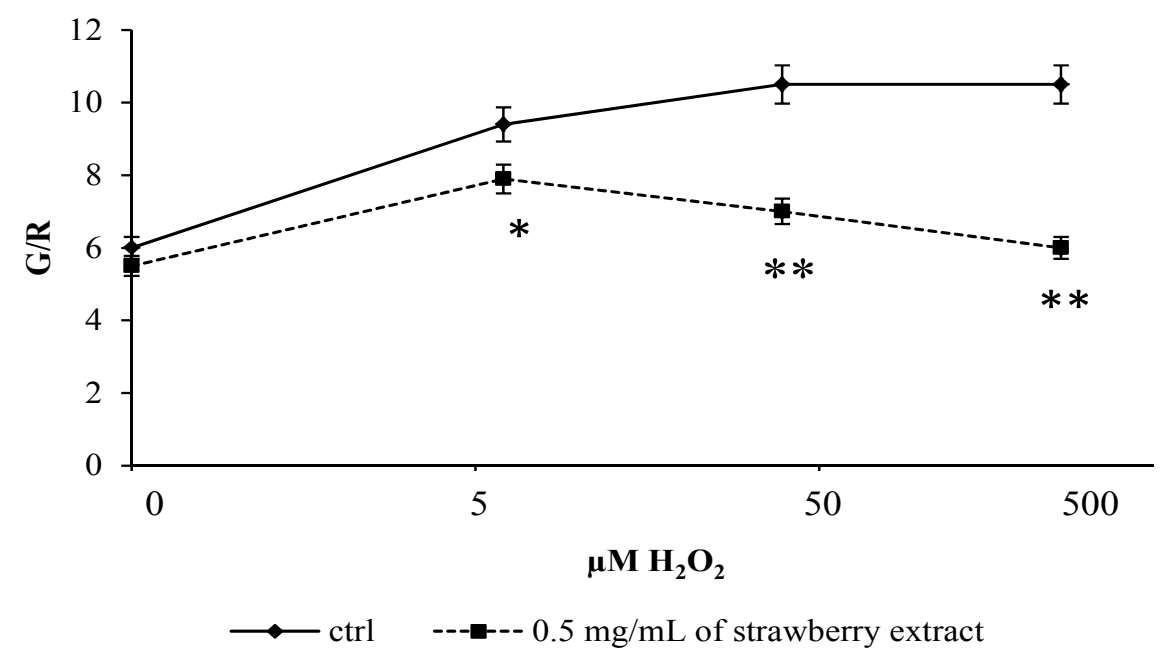




\subsection{Mitochondrial Functionality}

In eukaryotic cells mitochondrial energy metabolism is recognized as the main source of ROS, which can increase because of extracellular oxidative damage. We tested the effect of strawberry extract in protecting mitochondrial bioenergetics against oxidative damage mediated by hydrogen peroxide, which can act as a physiological stressor agent in human dermal fibroblasts. To examine the potential improvement of strawberries on mitochondrial function, the oxygen consumption rate (OCR) was measured in control and pre-treated cells, exposed sequentially to each of three well-defined small modulators of oxidative phoshorylation: oligomycin, 2,4-dinitrophenol (2,4-DNP) and rotenone (Figure 5A).

Figure 5. Evaluation of oxygen consumption rate (OCR) in control and in strawberry pre-treated fibroblasts, stressed with $\mathrm{H}_{2} \mathrm{O}_{2}$. OCR was monitored through Seahorse XF-24 Extracellular Flux Analyzer with the sequential injection of Oligomycin $(1 \mu \mathrm{g} / \mathrm{mL})$, 2,4-DNP $(100 \mu \mathrm{M})$, Rotenone $(1 \mu \mathrm{M})$ at the indicated time point into each well, after baseline rate measurement (A). Basal OCR levels in control, strawberry pre-treated fibroblasts and in cells stressed with $\mathrm{H}_{2} \mathrm{O}_{2}$ with and without pretreatment with the strawberry extract $(\mathbf{B})$.

A

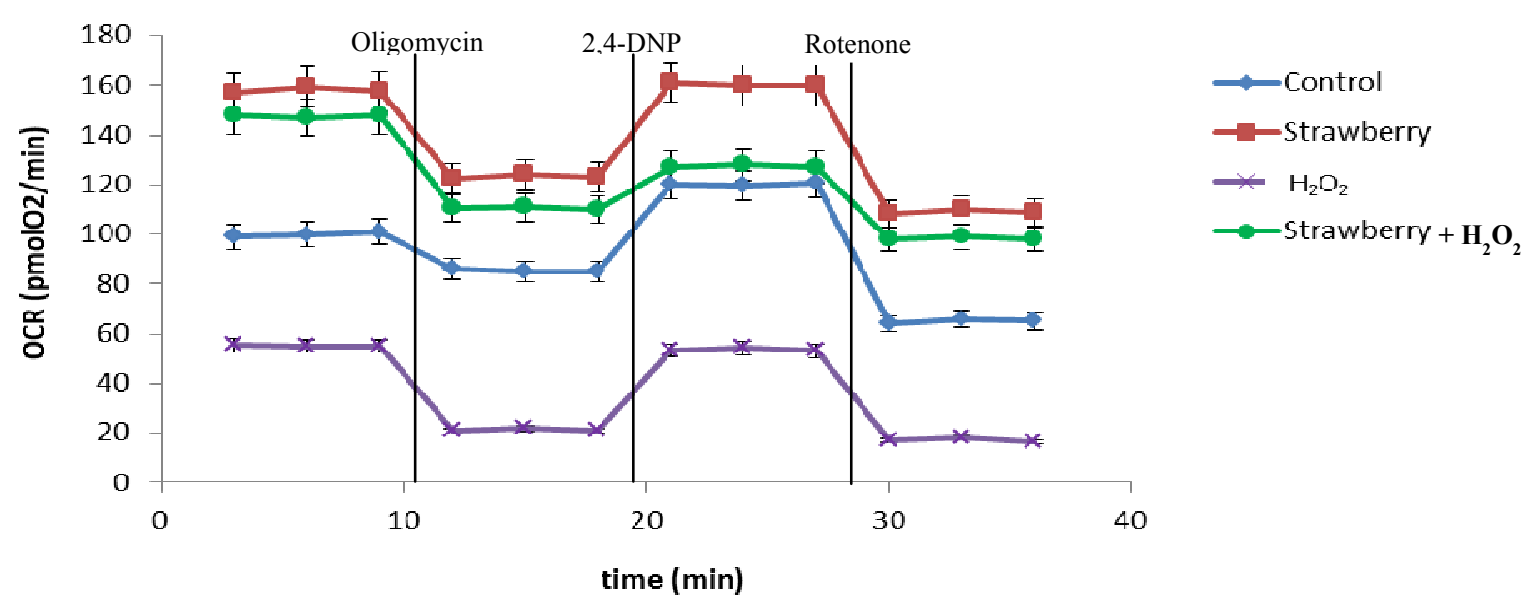

B

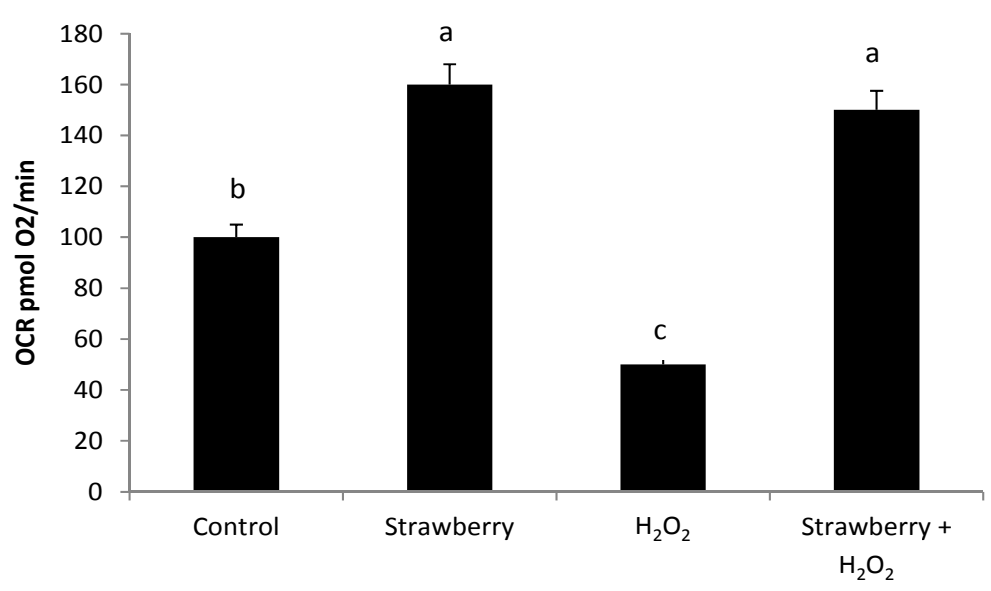


The treatment with $\mathrm{H}_{2} \mathrm{O}_{2}$ markedly affected mitochondrial function, reducing the basal OCR values by approximately 1.80 fold compared to control cells, showing the damaging effect of this oxidizing agent on mitochondrial functionality. However, basal OCR was markedly improved $(p<0.05)$ in strawberry-treated cells, highlighting the protection of the extract against $\mathrm{H}_{2} \mathrm{O}_{2}$. The increase of basal OCR in cells after strawberry treatment was approximately 1.59 fold compared to control cells, while pre-treatment with strawberry extract before $\mathrm{H}_{2} \mathrm{O}_{2}$-induced oxidative damage increased basal OCR by approximately 2.70 fold compared to cells treated only with $\mathrm{H}_{2} \mathrm{O}_{2}$. Interestingly, strawberry treatment maintained basal OCR at similar levels in both treatments, demonstrating the possible effect that the bioactive compounds present in the extract may affect, directly or indirectly, mitochondrial functionality (Figure 5B).

Moreover, a similar response was observed in the sequence injections of mitochondrial inhibitors in all experimental groups. In all cases OCR levels were higher in cells pre-treated with strawberry extract, compared to untreated cells. Addition of oligomycin, a substrate that inhibits the ATP synthase activity, caused a significant decrease $(p<0.05)$ of the OCR rate in all samples. The subsequent addition of 2,4-DNP, an ionophore that allows the electron flux without ATP production, increased OCR in all groups and the final addition of rotenone, a substrate that inhibits flux electrons from complex I to Ubiquinone, caused a marked decrease of OCR in all experimental groups.

\subsection{Inhibition of DNA Damage}

The results of this study also show that Sveva extract protected HuDe cells and prevented DNA damage. Figure 6 shows results expressed as percentage of tail intensity, i.e., intensity of fluorescence in the comet tail which is considered the best parameter for evaluating the extent of cellular DNA damage [1]. DNA damage significantly $(p<0.05)$ decreased in pre-treated cells compared to controls, for concentration of $\mathrm{H}_{2} \mathrm{O}_{2} \geq 60 \mu \mathrm{M}$.

Figure 6. Comet assay after $\mathrm{H}_{2} \mathrm{O}_{2}$ stress. Cells were stressed with $\mathrm{H}_{2} \mathrm{O}_{2}$ for $15 \mathrm{~min}$, processed and analysed for DNA damage. The data are expressed as the percentage of intensity fluorescence in the comet tail (percentage tail intensity) in control and pre-treated cells and relate to three independent experiments performed in triplicate. Statistical analysis was performed with T-test. ${ }^{*} p<0.05$ significantly different from control.

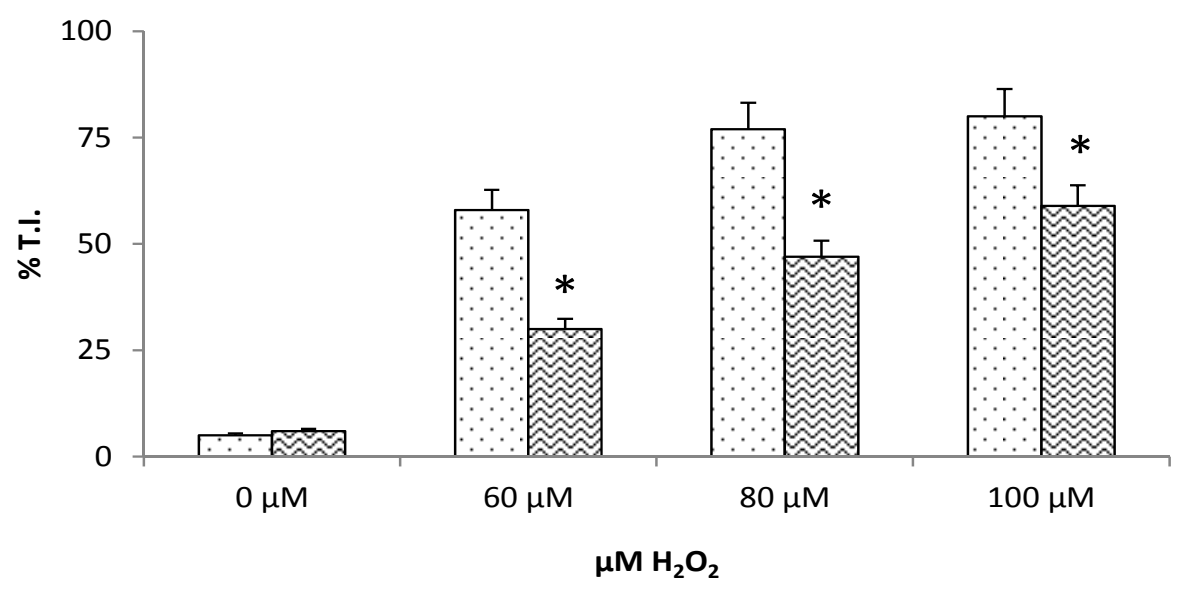

$\square$ control $\quad 0.5 \mathrm{mg} / \mathrm{mL}$ of strawberry extract 
Although anthocyanins are well known to have antioxidant activity [19-21], there is very limited evidence about the protective role of these substances against DNA damage. As previously reported by Ghosh et al. [22] anthocyanins and phenolic fractions of blackcurrants were more effective in protecting DNA of HL-60 human promyelocytic cells from damage than similar fractions from boysenberries. The phenolic extract of blackcurrants demonstrated the highest protective effect against $\mathrm{H}_{2} \mathrm{O}_{2}$-induced neurotoxicity, oxidative stress and DNA damage. Another study reported that anthocyanin-rich blackberry extract is able to suppress DNA-damaging properties of topoisomerase I and II poisons in colon carcinoma cells. Interestingly, the authors demonstrated that anthocyanidin delphinidin acts as a catalytic topoisomerase inhibitor suppressing the DNA-strand breaking effects of different topoisomerase poisons [23].

Figure 7. MTT and recovery after stress by $\mathrm{H}_{2} \mathrm{O}_{2}$. Control and pre-incubated cells were stressed with different concentrations of $\mathrm{H}_{2} \mathrm{O}_{2}(0.1,0.5$ and $1 \mathrm{mM})$ and analysed in different times to assess the percentage of vitality. At 0 and $24 \mathrm{~h}$ after stress, the difference from controls was significant for concentrations of hydrogen peroxide $\geq 500 \mathrm{mM}$. After $72 \mathrm{~h}$ the two curves differed for all the experimental points. Data are expressed as mean \pm SEM for eight replicas $(n=8)$ of three independent experiments. Statistical analysis was performed with the T-test. $* p<0.05$ significantly different from control, $* * p<0.01$ highly significantly.
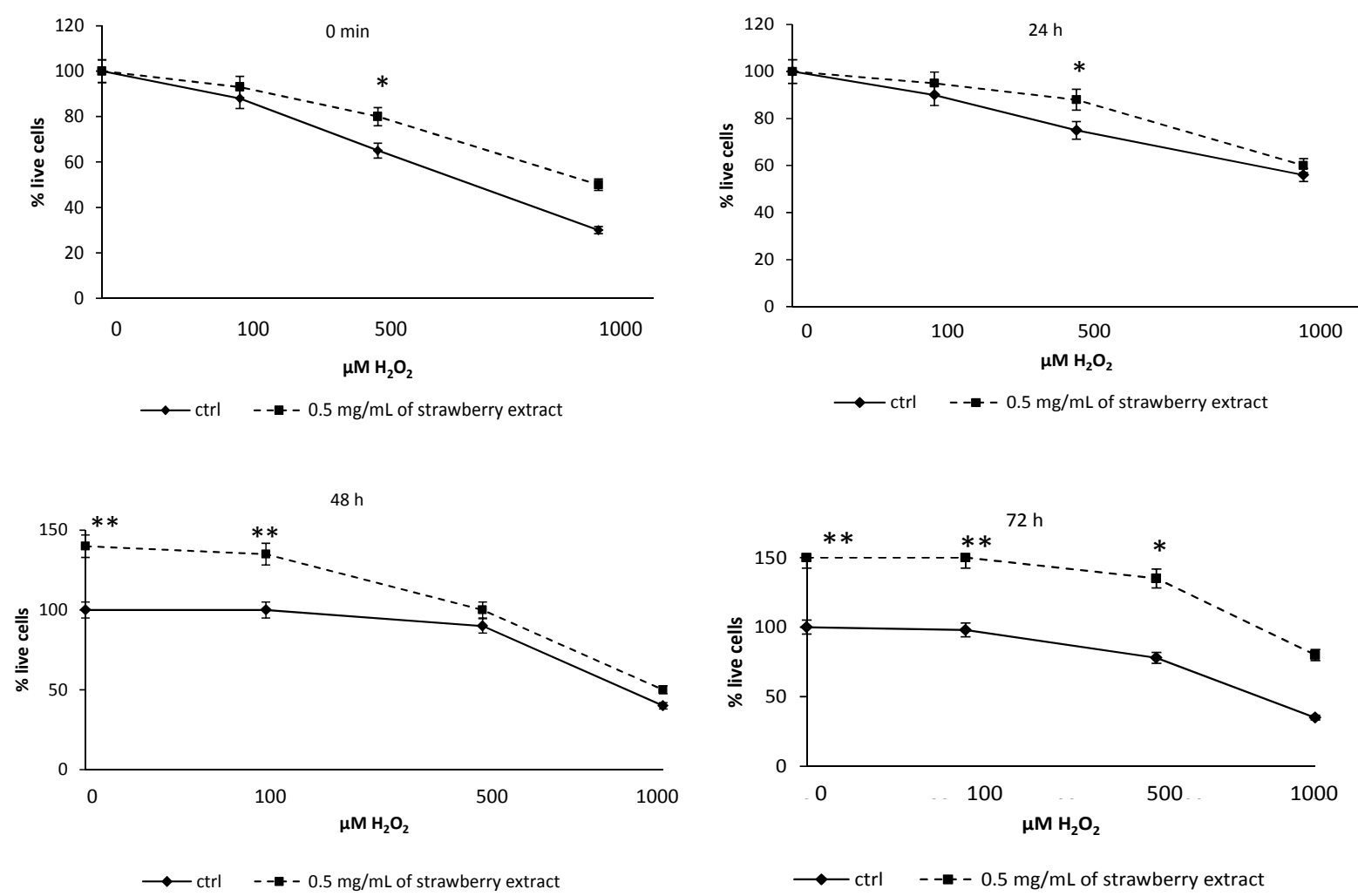

\subsection{Cell Proliferation and Recovery Assay}

With MTT viability assay it was possible to assess whether strawberry extract was also able to influence the recovery of cell viability after prolonged oxidative stress to different $\mathrm{H}_{2} \mathrm{O}_{2}$ 
concentrations. As demonstrated in tests of viability for control and pre-treated cells, the curve of pretreated cell viability showed a significant difference $(p<0.05)$ with controls for concentrations of $\mathrm{H}_{2} \mathrm{O}_{2} \geq 500 \mu \mathrm{M}$. After $24 \mathrm{~h}$ (Figure 7) the significance of recovery was recorded only for cells stressed with $500 \mu \mathrm{M} \mathrm{H}_{2} \mathrm{O}_{2}$. After a further $24 \mathrm{~h}$, the difference between the two curves became highly significant $(p<0.01)$ for $\leq 50 \mu \mathrm{M} \mathrm{H}_{2} \mathrm{O}_{2}$ and this difference remained after $72 \mathrm{~h}$, when the significance was recorded for all stress points analyzed. In conclusion, evidence of recovery revealed a significant restoring of vitality and cell function after 48 and $72 \mathrm{~h}$ from stress induced by $\mathrm{H}_{2} \mathrm{O}_{2}$.

\section{Experimental}

\subsection{Chemicals}

All solvents were HPLC grade. 2,2'-Azinobis(3-ethylbenzothiazolne-6-sulfonic acid) diammonium salt (ABTS), sodium chloride $(\mathrm{NaCl})$, agarose, hydrogen peroxide $\left(\mathrm{H}_{2} \mathrm{O}_{2}\right)$, ferrous sulphate $\left(\mathrm{FeSO}_{4}\right)$ and all other reagents and solvents were purchased from Sigma-Aldrich Chemie GmbH (Steinheim, Germany). C11-BODIPY was obtained from Molecular Probes (Invitrogen, Milan, Italy) and Minisart filter from PBI International. Essential Modified Eagle Medium (EMEM) and all the other products for cell culturewere purchased from Cambrex (Milan, Italy).

\subsection{Strawberry Material and Sample Preparation}

Ripe fruits from strawberries of the Sveva cultivar were harvested from plants grown in an open experimental field for strawberry breeding and germplasm collection at the Azienda Agraria Didattico Sperimentale "P. Rosati" in Agugliano (Ancona, Italy). Within $2 \mathrm{~h}$ after harvest, whole fruits were stored at $-80{ }^{\circ} \mathrm{C}$ for further analysis.

For the analysis of phytochemicals, total antioxidant capacity (TAC) and for cell treatment, the hydroalcoholic extract was obtained from $10 \mathrm{~g}$ of fruits homogenised for $2 \mathrm{~min}$ in $100 \mathrm{~mL}(1: 10 \mathrm{w} / \mathrm{v})$ of extraction solution ( $80 \%$ methanol aqueous solution acidified with $0.1 \%$ formic acid) using an Ultraturrax T25 homogeniser (Janke \& Kunkel, IKA Labortechnik, Staufen, Germany). After homogenization the extraction was maximised by stirring the suspension for $2 \mathrm{~h}$ at $4{ }^{\circ} \mathrm{C}$ in the dark. The mixture was then centrifuged at $1200 \mathrm{xg}$ for $15 \mathrm{~min}$ (twice sequentially), to sediment solids, supernatants were filtered through a $0.45 \mu \mathrm{m}$ Minisart filter (PBI International), transferred to $5 \mathrm{~mL}$ amber glass vials and stored at $-80{ }^{\circ} \mathrm{C}$ prior to analysis.

For the HPLC-DAD-MS identification and quantification of anthocyanin, extraction and purification was performed as previously described [24] using a C-18 SepPaks Vac 6cc cartridge (Waters, Milan, Italy). Frozen strawberries $(50 \mathrm{~g})$ were homogenized in methanol containing $0.1 \%$ $\mathrm{HCl}$, kept overnight $(\sim 14 \mathrm{~h})$ at $4{ }^{\circ} \mathrm{C}$ and later filtered through a Büchner funnel under vacuum. The solid residue was exhaustively washed with methanol and the filtrates obtained were centrifuged (4000 $\mathrm{xg}, 15 \mathrm{~min}, 20^{\circ} \mathrm{C}$ ). The resulting extract was washed with $n$-hexane to eliminate liposoluble substances and then an aliquot $(4 \mathrm{~mL})$ was deposited onto a C-18 SepPaks Vac 6 cc cartridge (Waters) previously conditioned with methanol and washed with ultrapure water. Sugars and more polar substances were eluded with $15 \mathrm{~mL}$ of ultrapure water while anthocyanin pigments were eluted with $5 \mathrm{~mL}$ of methanol: $0.1 \%$ TFA (95:5). The methanolic extract was concentrated under vacuum in a 
rotary evaporator and the extract was then collected, brought to $2 \mathrm{~mL}$ of volume with ultrapure water and filtered through a $0.45-\mathrm{mm}$ membrane filter (PBI international, Milan, Italy) for HPLC analysis.

For vitamin $\mathrm{C}$ determination, fruits stored at $-80{ }^{\circ} \mathrm{C}$ were ground to a fine powder using a precooled coffee grinder (IKA A11 basic). Immediately before analysis, $2 \mathrm{~mL}$ of ice-cold extraction solution was added to $0.5 \mathrm{~g} \mathrm{FW}$ frozen powder weighed in $10 \mathrm{~mL}$ ice-cold glass tubes, and the mixture sonicated at $4{ }^{\circ} \mathrm{C}$ for $15 \mathrm{~min}$ in the dark. The extraction solution consisted in MilliQ water containing $5 \%$ meta-phosphoric acid and $1 \mathrm{mM}$ EDTA, stirred well prior to use, sonicated until dissolved and stored in the refrigerator. After the ultra-sound assisted extraction, cell walls and proteins were precipitated by centrifugation at $2500 \mathrm{rpm}$ for $10 \mathrm{~min}$ at $4{ }^{\circ} \mathrm{C}$, the surnatant was filtered through a $0.2 \mu \mathrm{m}$ PTFE filter into $1.8 \mathrm{~mL}$ HPLC vials, and immediately analysed.

For $\beta$-carotene analysis, $30 \mathrm{~mL}$ acetone were added to $5 \mathrm{~g}$ of freeze-dried fruits powder, sonicated for $15 \mathrm{~min}$, stirring for $1 \mathrm{~h}$ in the dark at room temperature and centrifuged twice at $9500 \times \mathrm{g}$ at $4{ }^{\circ} \mathrm{C}$ for $15 \mathrm{~min}$. The extract was combined and brought to final volume of $100 \mathrm{~mL}$, and $50 \mathrm{~mL}$ of methanolic $\mathrm{KOH}(10 \%)$ was added for saponification at room temperature overnight. The extract was then transferred to $100 \mathrm{~mL}$ petroleum ether and the organic layer was dried. The dried residue was dissolved in hexane and filtered through a $0.45 \mu \mathrm{m}$ membrane filter for HPLC analysis.

\subsection{Measurement of Total Phenolic Content}

The total phenolic content of the hydrophilic extracts was determined using the Folin-Ciocalteu colorimetric method, as modified by Slinkard and Singleton [25]. Briefly, $100 \mu \mathrm{L}$ of alternatively blank (milliQ water), water diluted strawberry extracts or gallic acid standard solutions $(1 / 10)$ were added to $500 \mu \mathrm{L}$ of Folin-Ciocalteau reagent previously water diluted $(1 / 10)$ and kept at $4{ }^{\circ} \mathrm{C}$, in the dark. The mixture was incubated for 1 to $8 \mathrm{~min}$ at room temperature, then $400 \mu \mathrm{L}$ of $0.7 \mathrm{M}$ sodium carbonate $\left(\mathrm{Na}_{2} \mathrm{CO}_{3}\right)$ was added and the mixture vortexed well. The solution was incubated for $2 \mathrm{~h}$ at room temperature $\left(\sim 23{ }^{\circ} \mathrm{C}\right)$, in the dark, then the specific absorbance at $760 \mathrm{~nm}$ was read. A methanol-water $(80: 20, \mathrm{v} / \mathrm{v})$ solution of $6 \mathrm{mM}$ gallic acid (GA) was prepared, and stored at $4{ }^{\circ} \mathrm{C}$ for at maximum one week. Serial standard dilutions $(0.5-3.0 \mathrm{mM})$ were daily prepared from the stock solution, for quantifications. Calibration was obtained by plotting the known GA concentrations versus the corresponding absorbance760, and final results were expressed as milligrams of gallic acid equivalents per gram of fresh weight of strawberry [mg GAEq/g FW] (mean value of eight technical replicates) \pm SEM.

\subsection{Measurement of Total Flavonoid Content}

Total flavonoid content was determined by using a colorimetric method described previously [26]. Briefly, $250 \mu \mathrm{L}$ of alternatively blank (water), strawberry hydrophylic extract or $(+$ )-Catechin standard solution was mixed to $1.25 \mathrm{~mL}$ of MilliQ water in a test tube, following by addition of $75 \mu \mathrm{L}$ of a $5 \%$ sodium nitrate $\left(\mathrm{NaNO}_{2}\right)$ solution. After $6 \mathrm{~min}, 150 \mu \mathrm{L}$ of a $10 \%$ aluminium chloride hexahydrate $\left(\mathrm{AlCl}_{3} \cdot 6 \mathrm{H}_{2} \mathrm{O}\right)$ solution was added to the mixture, and allowed to stand for $5 \mathrm{~min}$. Then, $500 \mu \mathrm{L} 1 \mathrm{M}$ sodium hydroxide $(\mathrm{NaOH})$ were added, the mixture was brought to $2.5 \mathrm{~mL}$ with MilliQ water and mixed well, and the absorbance was immediately read at $510 \mathrm{~nm}$ against blank. For quantitative results, from a methanol-water $(80: 20, \mathrm{v} / \mathrm{v})$ stock solution of $(+)$-catechin $(1 \mathrm{mg} / \mathrm{mL})$, serial standard 
dilutions were prepared $(0.0125-0.1 \mathrm{mg} / \mathrm{mL})$, and their known concentrations versus the corresponding absorbance were plotted. Results are expressed as mg of catechin equivalents per gram of fresh weight of strawberry [mg CEq/g FW] (mean value of eight technical replicates) \pm SEM.

\subsection{Determination of Vitamin $C$ and $\beta$-carotene}

Vitamin C was measured as described by Helsper and co-workers [27]. Strawberry extracts were subjected to HPLC analysis immediately after the extraction procedure. The HPLC system comprised a Waters 600 controller, a Waters 996 Photodiode array (PDA) detector set at absorbances of 262 and $244 \mathrm{~nm}$, and a column incubator at $30^{\circ} \mathrm{C}$. The HPLC column used was a YMC Pack Pro 150x4.6 mm. The elution was isocratic with $50 \mathrm{mM}$ potassium phosphate $\left(\mathrm{KH}_{2} \mathrm{PO}_{4}\right)$ in MQ water, leading to $\mathrm{pH} 3.2$ (below the $\mathrm{pKa}$ of the ascorbic acid) by adding orthophosphoric acid, and analysis consisted in a 10 minute run, after which the column was cleaned with $50 \%$ acetonitrile. Vitamin $\mathrm{C}$ eluted at $\mathrm{RT} \approx 5.3 \mathrm{~min}$. Quantification of the vitamin $\mathrm{C}$ content was carried out through a calibration curve prepared by running standard concentrations of vitamin $\mathrm{C}$ similarly prepared to the extracts, and measured in duplicate at the beginning and end of the analysis. Results are expressed as $\mathrm{mg}$ vitamin $\mathrm{C}$ per gram of fresh weight of strawberry [mg vit $\mathrm{C} / \mathrm{g} \mathrm{FW}$ ] (mean value of three technical replicates $\pm \mathrm{SEM}$ ).

$\beta$-Carotene content was determined with an HPLC method previously described by Zanatta et al. [28]. Samples were injected in the HPLC system with detector set at $445 \mathrm{~nm}$ at $30{ }^{\circ} \mathrm{C}$. The analytical column used was a Supelcosil ${ }^{\mathrm{TM}}$ LC-18 $(150 \times 4.6 \mathrm{~mm})$ and the mobile phase was acetonitrile-methanol-ethyl acetate $(88: 10: 2 \mathrm{v} / \mathrm{v})$ in isocratic gradient flow at a rate of $1.0 \mathrm{~mL} / \mathrm{min}$. For quantification a $\beta$-carotene standard was used and results are expressed as $\mu \mathrm{g} \beta$-carotene per $100 \mathrm{~g}$ of FW.

\subsection{HPLC-ESI-MS Characterization of Strawberry Extract}

HPLC-DAD/ESI-MS analysis was performed using a Hewlett-Packard 1100 series liquid chromatograph (Agilent Technologies, Waldbronn, Germany) coupled to an HP ChemStation data-processing station [24]. The stationary phase used was a $5 \mu \mathrm{m} \mathrm{AQUA}^{\circledR} \mathrm{C} 18150 \mathrm{~mm} \times 4.6 \mathrm{~mm}$ column (Phenomenex, Torrance, CA) thermostatted at $35{ }^{\circ} \mathrm{C}$ and the mobile phase was: (A) $0.1 \%$ trifluoroacetic acid in water, and (B) HPLC-grade acetonitrile, using the following gradient: isocratic $10 \% \mathrm{~B}$ for $5 \mathrm{~min}, 10 \%-15 \%$ B over $15 \mathrm{~min}$, isocratic $15 \% \mathrm{~B}$ for $5 \mathrm{~min}, 15 \%-18 \% \mathrm{~B}$ over $5 \mathrm{~min}$, and $18 \%-35 \%$ B over $20 \mathrm{~min}$, with a flow rate of $0.5 \mathrm{~mL} \mathrm{~min}^{-1}$. Double on-line detection was performed using a diode array spectrophotometer (DAD) at $520 \mathrm{~nm}$ as the selected wavelength, and a mass spectrometer (MS) connected to the HPLC system via the DAD cell outlet.

The mass spectrometer (Finnigan LCQ, San Jose, CA, USA) was equipped with an ESI source and an ion trap mass analyzer, controlled by LCQ Xcalibur software. Nitrogen was used as both auxiliary and sheath gas at flow rates of 6 and $1.2 \mathrm{~L} \mathrm{~min}^{-1}$, respectively. The capillary voltage was $4 \mathrm{~V}$ and the capillary temperature $195{ }^{\circ} \mathrm{C}$. Spectra were recorded in positive ion mode between $\mathrm{m} / \mathrm{z} 150$ and 1500 . The MS detector was programmed to perform a series of three consecutive scans: a full scan, a zoom scan of the most abundant ion in the first scan and an MS-MS scan of the most abundant ion, using normalized collision energy of $45 \%$. Anthocyanins were identified and quantified from the areas of 
chromatographic peaks by comparison with calibration curves obtained with external standards of Cyanidin-3-glucoside (Cy-3-gluc) and of Pelargonidin 3-glucoside (Pg-3-gluc).

\subsection{Total Antioxidant Capacity}

The TAC of the strawberry extract was determined by the Trolox Equivalent Antioxidant Capacity (TEAC) and the Ferric Reducing Antioxidant Power (FRAP) assays. The TEAC assay was carried out according to the modified method of Re and co-workers [29] and combined to a flow injection analysis (FIA) system [30]. The strawberry extract $(10 \mu \mathrm{L})$ was injected into a serpentine-knotted reaction coil and allowed to react with the ABTS+ solution pumped at a flow of $1.2 \mathrm{~mL} / \mathrm{min}$ into the coil. The extent of decolorization, expressed as percentage of inhibition of absorbance, is then plotted as a function of concentrations of the antioxidant capacity in the sample. TEAC results are expressed as micromoles of Trolox equivalents per gram of FW of strawberry. Data are reported as a mean value \pm SEM for four measurements.

The FRAP assay was carried out according to the protocol proposed by Deighton and co-workers [31]. The FRAP reagent solution was prepared daily immediately prior to procedure, by combining ten volumes of sodium acetate (300 mM, pH 3.6) with one volume of TPTZ (10 mM in HCl $40 \mathrm{mM})$ and one volume of ferric chloride $(20 \mathrm{mM})$ aqueous solutions. Briefly, $100 \mu \mathrm{L}$ of alternatively blank, Trolox standard or 10-fold milliQ water diluted strawberry extract were added to $900 \mu \mathrm{L}$ FRAP reagent. The mixture was then quickly vortexed for $15 \mathrm{~s}$ (starting the timer immediately) and allowed to stand for $4 \mathrm{~min}$. After exactly $4 \mathrm{~min}$, the absorbance of the solution was read at $593 \mathrm{~nm}$ (model DU644 spectrophotometer, Beckman, Fullerton, CA, USA) against blank. Trolox aqueous dilutions were used for calibration. Each sample was analyzed in eight replicates and FRAP results were expressed as micromoles of Trolox equivalents per gram of FW of strawberry. Data are reported as a mean value \pm SEM for four measurements.

\subsection{Culture of HuDe Cell Line and Cell Treatment}

Primary Human Dermal Fibroblasts $(\mathrm{HuDe})$ isolated from adult skin were purchased from the Central Laboratory of Istituto Zooprofilattico Sperimentale (Brescia, Italy). Cells were cultured in EMEM (Cambrex, Milan, Italy) supplemented with 10\% foetal bovine serum (FBS), $2 \mathrm{mM}$ glutamine and antibiotics (100 IU/mL penicillin and $100 \mu \mathrm{g} / \mathrm{mL}$ streptomycin), at $37{ }^{\circ} \mathrm{C}$ in a humidified atmosphere with $5 \% \mathrm{CO}_{2}$.

Strawberry extract was concentrated under vacuum to eliminate total ethanol and resuspended in EMEM to achieve a final concentration of $0.500 \mathrm{mg} / \mathrm{mL}$, reported in our previous work [1]. Cells were incubated for $24 \mathrm{~h}$ with Sveva extract. After incubation and prior to stress induction the cells were washed twice with PBS, to prevent direct extracellular interactions between the extract compounds and $\mathrm{H}_{2} \mathrm{O}_{2}$, and then exposed to the stressor added to the culture medium at different concentrations and time, according to previously cytotoxicity studies conducted for each test. Control cells were incubated only in EMEM. 


\subsection{Cell Viability Assay}

Cell viability was determined using the MTT assay [32]. Control and pre-incubated cells were stressed with different concentrations of $\mathrm{H}_{2} \mathrm{O}_{2}(0-50 \mathrm{mM})$ for $2 \mathrm{~h}$. After incubation, fibroblasts were washed twice with PBS and incubated with a salt solution of MTT at a concentration of $0.5 \mathrm{mg} / \mathrm{mL}$ for $2 \mathrm{~h}$ at $37{ }^{\circ} \mathrm{C}$. This assay is based on the reduction of the tetrazolium salt, 3-(4,5-dimethylthiazol-2-yl)-2,5-diphenytetrazolium bromide, by intracellular dehydrogenases of viable living cells, leading to the formation of purple formazan crystals. The medium was then removed and the crystals were dissolved in DMSO. Optical density was read at $550 \mathrm{~nm}$ using a microplate reader (Synergy HT, Biotek, Winooski, VT, USA). Cell viability was expressed as a percentage of live cells compared to unexposed control. The data reported represent average values from at least three independent experiments.

\subsection{Evaluation of Intracellular ROS}

After pre-incubation with Sveva extract cells were incubated with different concentrations of $\mathrm{H}_{2} \mathrm{O}_{2}$ $(0-10 \mathrm{mM})$ and the kinetic production of intracellular ROS was followed for two hours, with readings taking place every 15 min [33]. After treatment with the stressor, cells were washed twice with PBS and incubated with a $20 \mu \mathrm{M}$ solution of DCFH-DA for $30 \mathrm{~min}$, at $37^{\circ} \mathrm{C}$. Intracellular ROS production was determined kinetically by the change of fluorescence signal (excitation and emission wavelengths: $488 \mathrm{~nm}$ and $510 \mathrm{~nm}$, respectively) using a microplate reader (Synergy HT).

\subsection{Evaluation of Membrane Lipid Peroxidation}

Lipid peroxidation was estimated using the C11-BODIPY, a red fluorescent fatty acid probe used for indexing lipid peroxidation and antioxidant efficacy in living cells [34]. Cells were incubated with $5 \mu \mathrm{M} \mathrm{C11-BODIPY} \mathrm{for} 30 \mathrm{~min}$ at $37{ }^{\circ} \mathrm{C}$, and after washing with PBS were stressed with various concentrations of $\mathrm{H}_{2} \mathrm{O}_{2}(0-500 \mu \mathrm{M})$. Oxidant action was evaluated for two hours in relation to changes in the relationship between the two fluorescences (excitation wavelength at $485 \mathrm{~nm}$ and a double emission wavelength at 528 and $590 \mathrm{~nm}$ ) using a fluorescence microplate reader (Synergy HT). The extent of lipid peroxidation was quantified as a percentage of red fluorescence increase in pre-treated cells compared to the control.

\subsection{Evaluation of Mitochondria Respiration}

Oxygen consumption rate (OCR) in fibroblasts was measured in real-time using a XF-24 Extracellular Flux Analyzer (Seahorse Bioscience, Billerica, MA, USA) [35]. Cells $\left(2 \times 10^{4}\right.$ cells/well) were seeded in the XF-24 plate and incubated for $24 \mathrm{~h}$ with the strawberry extract $(0.50 \mathrm{mg} / \mathrm{mL})$. After pre-incubation, cells were exposed to $\mathrm{H}_{2} \mathrm{O}_{2}(5 \mathrm{mM})$ for $1 \mathrm{~h}$, according to studies previously conducted to determine the concentration of $\mathrm{H}_{2} \mathrm{O}_{2}$ and time of exposition in order to obtain a reduction of the mitochondrial respiratory capacity of approximately $70 \%$ compared to control cells. The medium was then replaced with $450 \mu \mathrm{L}$ of XF-24 running media and the plate was incubated at $37{ }^{\circ} \mathrm{C}$ for $60 \mathrm{~min}$ in the XF Prep Station incubator (Seahorse Bioscience). The plate was transferred to the XF24 Extracellular Flux Analyzer and after the measurement of basal OCR a profiling of mitochondrial 
function was performed by sequential injection of three compounds that affect bioenergetics, as follows: $55 \mu \mathrm{L}$ of Oligomycin (final concentration $1 \mu \mathrm{g} / \mathrm{mL}$ ) at injection in port $\mathrm{A}, 61 \mu \mathrm{L}$ of 2,4-dinitrophenol (2,4-DNP) (final concentration $100 \mu \mathrm{M}$ ) at injection in port $\mathrm{B}, 68 \mu \mathrm{L}$ of rotenone/Antimycin A (final concentration $1 \mu \mathrm{M}$, respectively) at injection in port $\mathrm{C}$. The readings were performed three times for each inhibitor with three min given for each reading and data were expressed as $p$ mol of $\mathrm{O}_{2}$ consumed per minute.

\subsection{Evaluation of DNA Damage}

Comet assay was performed as described by Singh et al. [36] with some modifications [37]. Briefly, cells cultured in 12-well plates were washed twice with PBS and stressed with different concentrations of $\mathrm{H}_{2} \mathrm{O}_{2}(0-100 \mu \mathrm{M})$. PBS was then removed; cells were detached by trypsinization and resuspended in EMEM. Cells were centrifuged for $15 \mathrm{~min}$ at $1,000 \times g$ at $4{ }^{\circ} \mathrm{C}$ and aliquots containing $\sim 50,000$ cells were resuspended in $110 \mu \mathrm{L}$ of $1 \%$ low melting agarose. Then $50 \mu \mathrm{L}$ of these were placed on a $1 \%$ normal melting agarose precoated and dried microscope slide and immediately spread by covering with a coverslip, then the microgel on the slides was allowed to solidify at $4{ }^{\circ} \mathrm{C}$. The cover glasses were removed and the slides were immersed in ice-cold, freshly prepared lysis solution $(2.5 \mathrm{M} \mathrm{NaCl}$, $100 \mathrm{mM} \mathrm{Na} 2 \mathrm{EDTA}, 10 \mathrm{mM}$ Tris-HCl, 1\% Triton X-100, and 10\% DMSO, adjusted to $\mathrm{pH} \mathrm{10)} \mathrm{for} 15 \mathrm{~h}$, at $4{ }^{\circ} \mathrm{C}$ in the dark. After removing the slides from the lysis solution these were submerged in an alkaline buffer containing $1 \mathrm{mM} \mathrm{NaOH}, \mathrm{pH}$ 13, for $20 \mathrm{~min}$ in a horizontal electrophoresis box and electrophoresed for $20 \mathrm{~min}$ at $1 \mathrm{~V} / \mathrm{cm}$ at room temperature. After electrophoresis, the slides were washed gently with $0.4 \mathrm{M} \mathrm{M}$ Tris- $\mathrm{HCl}$ buffer $(\mathrm{pH} 7.5)$ to neutralize the excess alkali and to remove detergents. Successively the slides were dehydrated in $75 \%$ methanol for $5 \mathrm{~min}$ and dried at $60{ }^{\circ} \mathrm{C}$ for $15 \mathrm{~min}$ and then stained by adding $100 \mu \mathrm{L}$ of ethidium bromide $(20 \mathrm{mg} / \mathrm{mL})$. The analysis was performed using a 20X objective on a fluorescence microscope (Nikon Eclipse E600, Nikon Corporation, Tokyo, Japan) using FITC filters (490 nm excitation/520 nm emissions) and the comet images were analyzed using a CCD camera connected to HP computer. For each sample, 50 comets on two different slides (i.e., 100 comets/sample) were evaluated in each experiment. DNA damage on the slides was quantified by determining the fluorescence intensity in the tail (\% tail intensity). 150 randomly selected cells per slide were scored for each sample.

\subsection{Cell Proliferation Assay}

To evaluate the effect of Sveva extract in the recovery of pre-treated cells after prolonged oxidative stress following exposure to $\mathrm{H}_{2} \mathrm{O}_{2}(0.1,0.5$ and $1 \mathrm{mM})$ for $1 \mathrm{~h}$, cells at time 0 were immediately tested as described above with the MTT assay [32]. The remaining cells were incubated with fresh EMEM at $37^{\circ} \mathrm{C}$ for 24,48 and $72 \mathrm{~h}$ before being analyzed by the same assay viability.

\subsection{Statistical Analysis}

All results are expressed as means \pm SEM. Statistical analysis was performed using the one-way ANOVA and Turkey's Post Hoc Test; $p \leq 0.05$ was considered as significant and $p<0.01$ highly significant. 


\section{Conclusions}

Our results report that the Sveva strawberry cultivar has a high antioxidant capacity, as well as an important anthocyanin and vitamin content, which results in a protective effect on skin cells against damage induced by oxidative stress. Indeed, strawberry extract was effective in decreasing intracellular ROS concentration and in protecting lipid, DNA and mitochondrial functionality from the damage induced by free radicals.

Overall, the present study represents an interesting starting point for future investigations. Further studies will be of particular interest, in order to confirm our findings, to explore the direct and indirect antioxidant mechanisms underlying the beneficial effects of strawberry treatment, and to further investigate the role of specific classes of compounds in explaining the reported bioactivities.

Certainly, the authors are aware of the limitations of the study. Firstly, the absence of the key genes expression analysis, involved in antioxidant responses, is an important drawback of the study, since it could have been useful to further corroborate the role of strawberry extract on the results obtained. Another limit of the study is the lack of measurement of DNA damage and cell cycle of key markers involved in cell proliferation by western blot, since it could be essential to examine the mechanisms thorough which strawberry extract contributes to attenuate cytotoxicity induced by hydrogen peroxide. Moreover, more in-depth analysis would have added important data to define the in vitro protective effects of strawberry bioactive compounds in different subcellular districts in the recovery from oxidative insults and to verify the bioavailability of these molecules in skin cells after dietary intake or topical application, in order that strawberries can be used also as a natural antioxidant for preventing skin aging and diseases.

\section{Acknowledgments}

The authors wish to thank Ms. Monica Glebocki for editing the manuscript.

\section{Author Contributions}

The article is a work of three cooperating groups. Part of this work was done in Spain under the guidance of Prof. Celestino Santos-Buelga and Ana M. Gonzàlez-Paramàs and other part was done in Italy under the guidance of Prof. Maurizio Battino. Francesca Giampieri, José M. Alvarez-Suarez, Luca Mazzoni, Tamara Y. Forbes-Hernandez and Massimiliano Gasparrini performed the experiments and analyzed the data together with Prof. Josè L. Quiles, Prof. Bruno Mezzetti, Dr. Stefano Bompadre and Prof. Maurizio Battino. Prof. Celestino Santos-Buelga, Prof. Bruno Mezzetti, Prof. Bruno Mezzetti, Dr. Stefano Bompadre and Prof. Maurizio Battino contributed reagents/materials/analysis tools. Francesca Giampieri and José M. Alvarez-Suarez wrote the paper.

\section{Conflicts of Interest}

The authors declare no conflict of interest. 


\section{References}

1. Giampieri, F.; Alvarez-Suarez, J.M.; Tulipani, S.; Gonzalez-Paramas, A.M.; Santos-Buelga, C.; Bompadre, S.; Quiles, J.L.; Mezzetti, B.; Battino, M. Photoprotective potential of strawberry (Fragaria $\times$ ananassa) extract against UV-A irradiation damage on human fibroblasts. J. Agric. Food Chem. 2012, 60, 2322-2327.

2. Oyewole, A.O.; Wilmot, M.C.; Fowler, M.; Birch-Machin, M.A. Comparing the effects of mitochondrial targeted and localized antioxidants with cellular antioxidants in human skin cells exposed to UVA and hydrogen peroxide. FASEB J. 2014, 28, 485-494.

3. Chen, Q.M.; Bartholomew, J.C.; Campisi, J.; Acosta, M.; Reagan, J.D.; Ames, B.N. Molecular analysis of $\mathrm{H}_{2} \mathrm{O}_{2}$-induced senescent-like growth arrest in normal human fibroblasts: p53 and $\mathrm{Rb}$ control G1 arrest but not cell replication. Biochem. J. 1998, 332, 43-50.

4. Zhou, Y.; Dong, Y.; Xu, Q.; He, Y.; Tian, S.; Zhu, S.; Zhu, Y.; Dong, X. Mussel oligopeptides ameliorate cognition deficit and attenuate brain senescence in D-galactose-induced aging mice. Food Chem. Toxicol. 2013, 59, 412-420.

5. Campisi, J.; d'Adda di Fagagna, F. Cellular senescence: When bad things happen to good cells. Nat. Rev. Mol. Cell Bio. 2007, 8, 729-740.

6. Kim, C.O.; Huh, A.J.; Han, S.H.; Kim, J.M. Analysis of cellular senescence induced by lipopolysaccharide in pulmonary alveolar epithelial cells. Arch. Gerontol. Geriatr. 2012, 54, e35-e41.

7. Demidenko, Z.N.; Blagosklonny, M.V. At concentrations that inhibit mTOR, resveratrol suppresses cellular senescence. Cell Cycle. 2009, 8, 1901-1904.

8. Draelos, Z.D. Aging skin: The role of diet: Facts and controversies. Clin. Dermatol. 2013, 31, 701-706.

9. Palmer, D.M.; Kitchin, J.S. Oxidative damage, skin aging, antioxidants and a novel antioxidant rating system. J. Drugs Dermatol. 2010, 9, 11-15.

10. Scalzo, J.; Politi, A.; Pellegrini, N.; Mezzetti, B.; Battino, M. Plant genotype affects total antioxidant capacity and phenolic contents in fruit. Nutrition 2005, 21, 207-213.

11. Tulipani, S.; Romandini, S.; Busco, F.; Bompadre, S.; Mezzetti, B.; Battino, M. Ascorbate, not urate, modulates the plasma antioxidant capacity after strawberry intake. Food Chem. 2009, 117, 181-188.

12. Alvarez-Suarez, J.M.; Dekanski, D.; Ristić, S.; Radonjić, N.V.; Petronijević, N.D.; Giampieri, F.; Astolfi, P.; González-Paramás, A.M.; Santos-Buelga, C.; Tulipani, S.; et al. Strawberry polyphenols attenuate ethanol-induced gastric lesions in rats by activation of antioxidant enzymes and attenuation of MDA. PLoS One 2011, 6, e25878.

13. Alvarez-Suarez, J.M.; Giampieri, F.; Tulipani, S.; Casoli, T.; di Stefano, G.; González-Paramás, A.M.; Santos-Buelga, C.; Busco, F.; Quiles, J.L.; Cordero, M.D.; et al. One-month strawberry-rich anthocyanins supplementation ameliorates cardiovascular risk, oxidative stress markers and platelets activation in humans. J. Nutr. Biochem. 2014, 25, 289-294.

14. Tulipani, S.; Armeni, T.; Giampieri, F.; Alvarez-Suarez, J.M.; Gonzalez-Paramás, A.M.; Santos-Buelga, C.; Busco, F.; Principato, G.; Bompadre, S.; Quiles, J.L.; et al. Strawberry intake increases blood fluid, erythrocyte and mononuclear cell defenses against oxidative challenge. Food Chem. 2014, 156, 87-93. 
15. Diamanti, J.; Capocasa, F.; Battino, M.; Mezzetti, B. Evaluation of $F$. $x$ ananassa intra-specific and inter-specific back-crosses to generate new genetic material with increased fruit nutritional quality. J. Berry Res. 2010, 1, 103-114.

16. Packer, L. Antioxidant action of carotenoids in vitro and in vivo protection against oxidation of human low-density lipoproteins. N. Y. Acad. Sci. 1993, 691, 48-60.

17. Solomon, A.; Golubowicz, S.; Yablowiz, Z.; Bergman, M.; Grossman, S.; Altman, A.; Kerem, Z.; Flaishman, M.A. Protection of fibroblasts (NIH-3T3) against oxidative damage by Cyanidin-3-rhamnoglucoside isolated from fig fruits (Ficus carica L.). J. Agric. Food Chem. 2010, 58, 6660-6665.

18. Kaneko, T.; Tahara, S.; Baba, N. Inhibition of linoleic acid hydroperoxide-induced toxicity in cultured human fibroblasts by anthocyanidins. Biosci. Biotechnol. Biochem. 2003, 67, 1391-1393.

19. Giampieri, F.; Tulipani, S.; Alvarez-Suarez, J.M.; Quiles, J.L.; Mezzetti, B.; Battino, M. The strawberry: Composition, nutritional quality, and impact on human health. Nutrition 2012, 28, 9-19.

20. Tumbas, V.; Canadanovic-Brunet, J.; Gille, L.; Dilas, S.; Cetkovic, G. Superoxide anion radical scavenging activity of bilberry (Vaccinum myrtillus L.). J. Berry Res. 2010, 1, 13-23.

21. Schantz, M.; Mohn, M.; Baum, M.; Richling, E. Antioxdative efficiency of an anthocyanin rich bilberry extract in the human colon tumor cell lines Caco-2 and HT-29. J. Berry Res. 2010, 1, 25-33.

22. Ghosh, D.; McGhie, T.; Zhang, J.; Adaim, A.; Skinner, M. Effects of anthocyanins and other phenolics of boysenberry and blackcurrant as inhibitors of oxidative stress and damage to cellular DNA in SH-SY5Y and HL-60 cells. J. Sci. Food Agric. 2006, 86, 678-686.

23. Esselen, M.; Barth, S.W.; Winkler, S.; Baechler, S.; Briviba, K.; Watzl, B.; Skrbek, S.; Marko, D. Anthocyanins suppress the cleavable complex formation by irinotecan and diminish its DNA-strand-breaking activity in the colon of Wistar rats. Carcinogenesis 2013, 34, 835-840.

24. Lopes da Silva, F.; Escribano-Bailon, M.T.; Perez Alonso, J.J.; Rivas-Gonzalo, J.; Santos-Buelga, C. Anthocyanin pigments in strawberry. LWT-Food Scien. Tech. 2007, 40, 374-382.

25. Slinkard, K.; Singleton, V.L. Total phenol analysis: Automation and comparison with manual methods. Am. J. Enol. Vitic. 1977, 28, 49-55.

26. Dewanto, V.; Wu, X.; Adom, K.K.; Liu, R.H. Thermal processing enhances the nutritional values of tomatoes by increasing the total antioxidant activity. J. Agric. Food Chem. 2002, 50, 3010-3014.

27. Helsper, J.P.F.G.; de Vos, C.H.R.; Maas, F.M.; Jonker, H.H.; van den Broeck, H.C.; Jordi, W.; Pot, C.S.; Keizer, L.C.P.; Schapendonk, A.H.C.M. Response of selected antioxidants and pigments in tissues of Rosa hybrida and Fuchsia hybrida to supplemental UV-A exposure. Physiol. Plantarum 2003, 117, 171-187.

28. Zanatta, C.F.; Mercadante, A.Z. Carotenoid composition from the Brazilian tropical fruit camu-camu (Myrciaria dubia). Food Chem. 2007, 101, 1526-1532.

29. Re, R.; Pellegrini, N.; Proteggente, A.; Pannala, A.; Yang, M.; Rice-Evans, C. Antioxidant activity applying an improved ABTS radical cation decolorization assay. Free Radic. Biol. Med. 1999, 26, 1231-1237.

30. Bompadre, S.; Leone, L.; Politi, A.; Battino, M. Improved FIA-ABTS method for antioxidant capacity determination in different biological samples. Free Radic. Res. 2004, 38, 831-838.

31. Deighton, N.; Brennan, R.; Finn, C.; Davies, H.V. Antioxidant properties of domesticated and wild Rubus species. J. Sci. Food Agric. 2000, 80, 1307-1313. 
32. Maines, M.D.; Costa, L.G.; Reed, D.J.; Sassa, S.; Sipes, I.G. Current Protocols in Toxicology; John Wiley \& Sons: New York, NY, USA, 1998.

33. Hempel, S.L.; Buettner, G.R.; O'Malley, Y.Q.; Wessels, D.A.; Flaherty, D.M. Hihydrofluorescein diacetate is superior for detecting intracellular oxidants: Comparison with 2',7'dichlorodihydrofluorescein diacetate, 5(and 6)-carboxy-2',7'-dichlorodihydrofluorescein diacetate, and dihydrorhodamine 123. Free Radic. Biol. Med. 1999, 27, 146-159.

34. Drummen, G.P.; van Liebergen, L.C.; Op den Kamp, J.A.; Post, J.A. C11-BODIPY (581/591), an oxidation-sensitive fluorescent lipid peroxidation probe: (micro) spectroscopic characterization and validation of methodology. Free Radic. Biol. Med. 2002, 33, 473-490.

35. Richardson, T.E.; Yu, A.E.; Wen, Y.; Yang, S.H.; Simpkins, J.W. Estrogen prevents oxidative damage to the mitochondria in Friedreich's ataxia skin fibroblasts. PLoS One 2012, 7, e34600.

36. Singh, N.P.; McCoy, M.T.; Tice, R.R.; Schneider, E.L. A simple technique for quantitation of low levels of DNA damage in individual cells. Exp. Cell Res. 1988, 175, 184-191.

37. Machella, N.; Battino, M.; Pisanelli, B.; Regoli, F. Influence of the SCGE protocol on the amount of basal DNA damage detected in the Mediterranean mussel, Mytilus galloprovincialis. Environ. Mol. Mutagen. 2006, 47, 579-586.

Sample Availability: Samples of the strawberry compounds are not available.

(C) 2014 by the authors; licensee MDPI, Basel, Switzerland. This article is an open access article distributed under the terms and conditions of the Creative Commons Attribution license (http://creativecommons.org/licenses/by/3.0/). 